Running head: SUBORDINATE CLAUSES IN L2 GERMAN AND L2 SWEDISH

The Development of Subordinate Clauses in German and Swedish as L2s: A Theoretical and Methodological Comparison

\title{
Kristof Baten
}

Ghent University, Research Foundation Flanders (FWO)

Gisela Håkansson

Lund University 


\begin{abstract}
In this article, we aim to contribute to the debate about the use of subordination as a measure of language proficiency. We compare two theories of SLA—specifically, processability theory (PT; Pienemann, 1998) and dynamic systems theory (de Bot, Lowie, \& Verspoor, 2007)—and, more particularly, their addressing of the development of subordinate clauses. Although DST uses measures from the complexity, accuracy, and fluency (CAF) research tradition (see Housen \& Kuiken, 2009), PT uses the emergence criterion to describe language development. We will focus on the development of subordinate clauses and compare how subordination as such is acquired and how the processing procedures related to a specific subordinate clause word order is acquired in the interlanguage (IL) of second language German and Swedish learners. The learners' language use shows that the use of subordination (as measured by a subordination ratio) fluctuates extensively. From the beginning of data collection, all learners use subordinate clauses, but their use of subordinate clauses does not increase linearly over time, which is expected by DST. When focusing on processability and the emergence of subordinate clause word order, however, a clear linear developmental sequence can be observed, revealing a clear difference between the nonacquisition and the acquisition of the subordinate clause word order rules. Our learner data additionally reveal a different behavior regarding lexical and auxiliary or modal verbs.
\end{abstract}




\section{The Development of Subordinate Clauses in German and Swedish as L2s: A Theoretical and Methodological Comparison}

The notion of developmental sequences can be considered as an accepted finding in second language acquisition (SLA) research (Long, 2007; VanPatten \& Williams, 2007), the existence of which is supported by robust evidence over the past 40 years (see Abrahamsson, 2013; Meisel, 2013). A promising explanation for developmental sequences has been put forward by processability theory (PT; Pienemann, 1998, 2005), which presents itself as a psycholinguistic theory of second language (L2) development. According to PT, L2 learners go through separate developmental stages that are implicationally ordered.

A recent challenge to this long-established finding, however, comes from the dynamic systems theory (DST) approach to SLA (de Bot, Lowie, \& Verspoor, 2007). DST scholars assert that it is time to reconsider whether universal orders really exist, given the high amount of variability present in learner language. In fact, de Bot et al. $(2007$, p. 8) claim that "the outcome of development over time can therefore not be calculated exactly." In this paper, we aim to demonstrate, however, that in addition to variability, IL systems do follow a highly regular and predictable pattern. We will discuss what kind of measures and evidence two SLA theories (i.e., PT and DST) use to describe and predict learners' IL systems.

Dynamic systems theory uses measures that are adopted from the complexity, accuracy, and fluency (CAF) research tradition (Bulté \& Housen, 2012; Housen \& Kuiken, 2009). In this tradition, subordinate clause ratios have made their mark as a measure of linguistic complexity. In fact, subordination ratios appeared as one of the more valid indicators of L2 proficiency as well as L2 development because they were seen as "consistently linear and significantly related to program or school level” (Wolfe-Quintero, Inagaki, \& Kim, 1998, p. 119). Subordination 
ratios and other CAF measures have been used as dependent as well as independent variables (Housen \& Kuiken, 2009). As dependent variables, one examines the possible effects of, for example, instruction or task type, on the measures of linguistic complexity. As independent variables, the measures of linguistic complexity are used as an index of L2 language proficiency and L2 development over time. It is this last use of linguistic complexity measures in which we are interested here.

Adopting such CAF measures as a way to investigate the dynamism of L2 development, DST studies (e.g., Larsen-Freeman, 2006) reveal that different participants follow different routes. Even though the group is making overall progress at the macrolevel, a look at the microlevel shows interindividual and intraindividual variability. In accordance with these kinds of findings, DST scholars deduce that development is not universally stagelike. We will argue, however, that CAF measures are misapplied in DST studies, as these measures may not be valid indicators of L2 development (e.g., Pallotti, 2013). We will, instead, adopt a method from PT, which will show that ILs follow strict developmental sequences. Our aim is not to argue for the abandonment of CAF measures, but rather to argue for dismissing the way DST interprets these measures (i.e., as evidence that linear developmental sequences do not exist and cannot be predicted).

To this aim, we will focus on the development of subordinate clauses in L2 German and L2 Swedish. We disentangle learners' problems with acquiring subordination (in the sense that one clause is being attached to another) from learners' problems with acquiring the internal structure of subordinate clauses. We explore both (a) how subordinate clauses as such are acquired and (b) how the subordinate clause word order is acquired. We discuss first the development of subordinate clauses, as measured by subordination ratios (Dynamic Systems 
Theory and Subordination Ratios), and then the emergence of subordinate clause word order (Processability Theory and the Emergence of Subordinate Clause Word Order). Regarding the emergence of word order, we discuss the acquisition of verb placement in L2 German and Swedish subordinate clauses. A challenge for learners of these languages is that the word order of subordinate clauses is different from the word order in main clauses. Both German and Swedish are verb-second (V2) languages, with the finite verb in the second position in declarative main clauses. The subordinate clauses of these languages, however, do not exhibit V2 word order. Subordinate clauses in German differ from main clauses by having the finite verb in the final position instead. Subordinate clauses in Swedish differ from main clauses by placement of the sentence adverbial (e.g., negation marker): in main clauses, the adverbial is placed after the finite verb; in subordinate clauses, the adverbial is placed before the finite verb. After a description of the word order rules in main clauses and subordinate clauses (Word Order Typology in German and Swedish) and a brief description of earlier studies on the acquisition of subordination in L2 German and L2 Swedish (Earlier Studies on the Acquisition of Subordination in L2 German and L2 Swedish), we present our empirical results (The Present Study: German and Swedish as L2s).

\section{Background}

\section{Dynamic Systems Theory and Subordination Ratios}

The DST approach is fairly recent in SLA research and can be traced back to LarsenFreeman (1997). In recent years quite a number of publications have discussed the characteristics of a DST approach to SLA (to name but a few: de Bot, Lowie, Thorne, \& Verspoor, 2013; de Bot et al., 2007; Larsen-Freeman \& Cameron, 2008; Verspoor, de Bot, \& Lowie, 2011). Due to limitations of space, we will only present the core principle here. 
The DST approach to SLA views language development as a complex process of dynamic construction, where all variables are interconnected: "changes in one variable will have an impact on all other variables that are part of the system" (de Bot et al., 2007, p. 8). Due to this interaction of variables over time, development becomes unpredictable. In other words, DST argues against a linear developmental path for each individual. Instead, "Learners do not progress through stages of development in a consistent manner. There is a great deal of variation at one time in learners' performances and clear instability over time" (Larsen-Freeman, 2006, p. 593).

To investigate how different variables interact over time, DST studies use CAF measures. In some such DST studies, it was found that the different variables (or subsystems) grow and decline at different rates. For example, the subsystems develop in a competitive interaction (e.g., when lexical complexity increases, syntactic complexity decreases; Verspoor, Lowie, \& Dijk, 2008), in a supportive interaction (e.g., when word complexity increases, noun phrase or sentence complexity also increase; Spoelman \& Verspoor, 2010), or in a precursor interaction (e.g., first the lexicon becomes more complex and accurate and then syntax becomes more complex and accurate; Caspi, 2010). Additionally, the variables reveal a nonlinear development with a lot of variation over time (Larsen-Freeman, 2006; Verspoor, Schmid, \& Xu, 2012). For example, in a longitudinal study over 6 months, Larsen-Freeman (2006) examined the CAF of five Chinese learners of English. Although the group mean showed a linear progression, the patterns of the interindividual and the intraindividual data exhibited very clear differences, as the learners progressed and regressed in widely varying ways.

Deducing from these findings that SLA research should focus on variation goes too far, according to Pallotti (2009, p. 590), who argued, in what he calls "the necessary variation 
fallacy," that SLA research should address not only variations and differences but also constants and similarities. We more than agree with this statement, but, at the same time, we argue that CAF measures may not give us the right tools to do this. Pallotti (2013) acknowledges this when he proposes a simple view of linguistic complexity (which is part of the CAF triad). He states that unnecessary assumptions (e.g., that complexity necessary grows over time and overlaps with other constructs such as L2 development) should be avoided. We believe that his warning applies not only to the construct of linguistic complexity but also to the CAF measures in general. Consequently, it seems unfounded to us that DST studies use CAF measures to demonstrate that L2 development is unpredictable and does not take place in stages. To show this, we will not discuss all possible CAF measures but will focus on linguistic complexity only.

The concept of linguistic complexity is often used to explain why some phenomena are acquired later than others in SLA (see, e.g., Housen \& Kuiken, 2009). For example, subordination is generally described as a complex feature, and its use (measured by, e.g., subordination ratios) thus appears late in L2 development. As one of the reviewers rightly pointed out, this kind of reasoning is circular, because "linguistic complexity" and “developmental timing" are conflated: Explaining the late acquisition of subordination by its complexity is just as fallacious as explaining its complexity by its late acquisition. One cannot simply appeal to complexity to explain the late acquisition of subordination and vice versa. From this circularity, it appears that the use of subordination ratios in particular, and CAF measures in general, may not be valid to show L2 development in terms of developmental timing.

Nevertheless, subordination ratios are widely used in the research literature. In their review of 16 studies in recent task-based language learning research, for example, Norris and Ortega (2009) found that subordination ratios were used in all 16 studies without fail. For several 
reasons, they added, this "exclusive reliance on subordination is worrisome" (p. 566; see also Bulté \& Housen, 2012). They noted, for example, that subordination ratios measure only one dimension of linguistic complexity, and, if subordination ratios are used as absolute indices for L2 development or L2 proficiency, they are in fact misapplied and liable to misinterpretation.

Previous research has shown that ratios such as subordination ratios exhibit large fluctuations owing to, for example, the oral versus the written language mode (Beaman, 1984), degree of syntactic integration (Gayraud \& Martinie, 2008), or task complexity (Robinson, 2011; Skehan \& Foster, 2009), both in native speakers and L2 learners. In this sense, we believe that the construct of linguistic complexity as measured by, for instance, subordination ratios is valid as a dependent variable but not as an independent variable indicating L2 development (which is to be understand here not in a general sense but in terms of developmental timing and sequences). Instead, we claim that the emergence of the subordinate clause procedure-Stage 5 in PT- is as a measure better suited to gauge L2 developmental sequences.

\section{Processability Theory and the Emergence of Subordinate Clause Word Order}

Different from the DST framework, variation and similarities are not considered as mutually exclusive entities in PT. In fact, variational and developmental features are described within a two-dimensional, and consequently nonlinear, space (this idea can be traced back to Meisel, Clahsen, \& Pienemann, 1981). This two-dimensional framework allows for steady development on the one hand and IL variation on the other. With respect to the acquisition of subordinate clauses, we hypothesize (in line with PT) that despite the variation the word order in the subordinate clause develops in a clear linear sequence (see the notion of hypothesis space below; Pienemann, 1998, p. 231 and the following pages). 
In PT, it is, in other words, not the use of subordinate clauses as such that matters but rather the internal properties of the subordinate clause (Pienemann, 1998, p. 107). Processability theory research has established that the subordinate clause word order emerges as the final stage in morphosyntactic development. ${ }^{1}$ Second language learners pass through a number of stages, which follow the different points in feature unification. Feature unification, adopted from lexicalfunctional grammar (LFG), is one of the fundamental principles in PT and refers to the compatibility of annotated features. For the unification of grammatical information to be possible, the information must be stored in a memory store (i.e., a syntactic buffer). The need to store grammatical information in a syntactic buffer comes with a cognitive cost, which rises proportionally with the duration for which it needs to be kept active in the memory store. Relying on Levelt's (1989) model of language production, PT describes the cumulative nature of unification points in a universal hierarchy of processability (see Pienemann, 1998, 2005):

1. No procedure (lemma access, chunks)

2. Category procedure

3. Phrasal procedure

4. Sentence procedure

5. Subordinate clause procedure (if applicable)

The first step for the L2 learner is to activate a lemma, including its syntactic category, on which a phrase can be built. Next, the phrase has to be assigned a grammatical function, which calls up a sentence procedure and eventually, if applicable, a subordinate clause procedure. The subordinate clause procedure is called for in languages in which the learner or speaker has to differentiate between the clausal structure in main and subordinate clauses. An example is the 
different positions of the verb in German, pre- or postverbal negation in Swedish, and the occurrence of inversion in direct, but not in indirect, questions in English.

In PT, research on syntactic development has mainly focused on the development of word order regularities of various languages, including L2 German and L2 Swedish (for German: Boss, 1996; Clahsen, 1984; Clahsen, Meisel, \& Pienemann, 1983; Ellis, 1989; Jansen, 2008; MeerholzHärle \& Tschirner, 2001; Meisel et al., 1981; Pienemann, 1984, 1989; for Swedish: Glahn et al., 2001; Håkansson, 2001; Håkansson \& Norrby, 2007, 2010; Philipsson, 2007; Pienemann \& Håkansson, 1999; Rahkonen \& Håkansson, 2008; Schönström, 2010). Different empirical studies have reported developmental sequences that are generally consistent with the processability hierarchy (see Table 1).

\section{INSERT TABLE 1 ABOUT HERE}

The first stages are similar in German and Swedish, but the stage regarding subordinate clauses differs to a certain extent, at least on the surface. Following LFG, however, the underlying rule system of the learner can be described in a similar way. To differentiate between a main clause and a subordinate clause, the learner annotates the complementizer with the additional feature ROOT $=-$. Relying on the lexical clue (hence LFG), the learner knows when a sentence is a main clause and when it is a subordinate clause and uses different word orders accordingly.

In the present paper, we do not aim to discuss the inter-stage development; instead, we focus on the intra-stage development at the final stage in the processability hierarchy (i.e., at the 
subordinate clause procedure). Particularly, we explore how word order rules develop in subordinate clauses.

\section{Word Order Typology in German and Swedish}

In this section, we provide a brief description of the basic word order pattern in the main and subordinate clauses in German and Swedish.

Main clauses. In the main clause, both languages make use of a basic subject-verb-object (SVO) word order, as illustrated by the c-structure rule and the sample sentences in (1). ${ }^{2}$

$\begin{array}{cccl}\text { (1) } \mathrm{S}-> & \mathrm{NP}_{\text {subj }} & \mathrm{V}_{\mathrm{FIN}} & \left(\mathrm{NP}_{\text {obj1 } 1}\right)\left(\mathrm{NP}_{\text {obj2 } 2}\right. \\ \text { Han } & \text { har } & \text { en hund } \\ \text { Er } & \text { hat } & \text { einen Hund }\end{array}$

"He has a dog."

In the case of complex verb phrases (VPs), Swedish VPs remain intact, whereas the verbs in German appear in a split position, as shown in (2a) and (2b), respectively.

(2) a. $\mathrm{S} \rightarrow \mathrm{NP}_{\text {subj }} \quad(\mathrm{V})_{\mathrm{FIN}} \quad(\mathrm{V})_{\mathrm{INF}} \quad\left(\mathrm{NP}_{\mathrm{obj} 1}\right)\left(\mathrm{NP}_{\mathrm{obj} 2}\right)$ Han har köpt en hund

"He has bought a dog."
b. $\mathrm{S}->\mathrm{NP}_{\text {subj }}$
$(\mathrm{V})_{\mathrm{FIN}}$
$\left(\mathrm{NP}_{\mathrm{obj} 1}\right)\left(\mathrm{NP}_{\mathrm{obj} 2}\right)$
$(\mathrm{V})_{\mathrm{INF}}$
Er
hat
einen Hund
gekauft

"He has bought a dog."

Subordinate clauses. The subordinate clause word order is different from the main clause in both languages. Recall that the ROOT feature refers to the lexical clue that distinguishes between a main and subordinate clause. 
In Swedish, differences arise in the context of sentence adverbials (e.g., negation particles). In main clauses, these adverbials occur after the finite verb, which ensures that the finite verb will always be in the V2 position (e.g., han har inte köpt en hund "He has not bought a dog"). In subordinate clauses, these adverbials occur before the finite verb, which results in an alternation between V2 in main clauses and V3 in subordinate clauses, as shown in the example in (3).

\begin{tabular}{|c|c|c|c|}
\hline $\mathrm{S}->\mathrm{COMP}_{\mathrm{ROOT}}=-$ & $\mathrm{NP}_{\text {subj }}$ & (NEG) & $(\mathrm{V})_{\mathrm{FIN}}(\mathrm{V})_{\mathrm{INF}}\left(\mathrm{NP}_{\mathrm{obj} 1}\right)\left(\mathrm{NP}_{\mathrm{obj} 2}\right)$ \\
\hline att & han & inte & har köpt \\
\hline "that & he & not & has bought \\
\hline
\end{tabular}

In German, main clause and subordinate clause word order are always different; it is obligatory to put the finite verb in the final position of the subclause, as shown in (4).

\begin{tabular}{|c|c|c|c|c|c|c|}
\hline \multirow{5}{*}{ (4) $\mathrm{S}->$} & $\mathrm{COMP}_{\mathrm{ROOT}=-}$ & $\mathrm{NP}_{\text {subj }}$ & $\left(\mathrm{NP}_{\mathrm{obj} 1}\right)\left(\mathrm{NP}_{\mathrm{o}}\right.$ & (NEG) & $(\mathrm{V})_{\mathrm{INF}}$ & $(\mathrm{V})_{\mathrm{FIN}}$ \\
\hline & dass & er & einen Hund & & gekauft & hat \\
\hline & "that & he & a dog & & bought & has" \\
\hline & dass & $e r$ & den Hund & nicht & gekauft & hat \\
\hline & "that & he & the dog & not & bought & has", \\
\hline
\end{tabular}

As many familiar with the acquisition of subordinate word order in German and Swedish are aware, these departures from main clause word order are more challenging learning issues than the use of subordinate clauses per se. This kind of learning challenge does not exist in English, where the word order in the subordinate clause does not differ from that in the main clause, as illustrated in $(5) .^{3}$
(5)
$\mathrm{S}->$
$\mathrm{COMP}_{\mathrm{ROOT}}=-\mathrm{NP}_{\text {subj }}$
$(\mathrm{V})_{\mathrm{FIN}}(\mathrm{V})_{\mathrm{INF}}\left(\mathrm{NP}_{\mathrm{obj} 1}\right)\left(\mathrm{NP}_{\mathrm{obj} 2}\right)$
that
he
has bought a dog

Earlier Studies on the Acquisition of Subordination in L2 German and L2 Swedish 
The results from L2 research have shown that the placement of the finite verb in subordinate clauses poses great difficulties to L2 German learners. Since the Zweitspracherwerb italienischer und spanischer Arbeiter "the second language acquisition of Italian and Spanish workers" project, which investigated the acquisition of German by migrant workers, established that the V-final rule is either acquired very late or even not at all (Clahsen et al., 1983; Meisel et al., 1981; Pienemann, 1980), several subsequent studies have replicated this finding (Boss, 1996; Clahsen, 1984; Ellis, 1989; Haberzettl, 2005; Jansen, 2008; Meerholz-Härle \& Tschirner, 2001; Pienemann, 1998). Although these studies differed in many respects (e.g., different first languages [L1s], adolescents vs. adults, naturalistic vs. instructed learning environment), they showed that the basic sequence with the acquisition of the V-final rule as the last stage is always the same (see Table 1).

It should be noted that this sequence was established in studies using the emergence criterion, which is defined by Meisel et al. (1981, p. 112) as counting "the numbers of actual occurrences relative to the total number of possible occurrences." Additionally, this sequence is to be interpreted in an implicational way, which means that the acquisition of the word order rule of a lower stage is a prerequisite for the acquisition of the word order rule of a higher stage.

Findings of studies on L2 Swedish have demonstrated a developmental order similar to that of German presented above: SVO < Adverb fronting (ADV) $<$ Inversion (INV) $<$ Subclause (see Table 1). This word order development has consistently been reported across a number of empirical studies (e.g., Håkansson \& Nettelbladt, 1993; Håkansson \& Norrby, 2010; Hammarberg \& Viberg, 1977; Hyltenstam, 1977); thus, although the Swedish subordinate clause word order does not have a V-End like the German subordinate clause word order, the Swedish subordinate clause word order structure is likewise the last to be acquired. 
Hyltenstam (1977) examined the variation in the placement of negation relative to the verb in learners of Swedish as a L2 and found that the variation was not random but highly regular. The placement of negation varied both according to clause type (main and subordinate clause) and according to verb type (main verbs and auxiliary or modal verbs). By using implicational scaling he was able to detect a path of development: For main clauses, the negation was first placed in the target position in the context of an auxiliary verb and then in the context of a main verb. In subordinate clauses, the order was reversed, as the target placement of negation emerged first in the context of a main verb and thereafter in the context of an auxiliary verb. Hyltenstam (1977) suggested that this gradual change of negative placement is a case of the "unlearning" phenomenon proposed by Jakobson (1941) and that negative placement is "another case where the last acquired is the first to be given up" (Hyltenstam, 1977, p. 409).

A lot of research on L2 morphosyntax has focused on discovering L2 developmental stages, where the acquisition of one stage was put in relation to the acquisition of another stage. As the results of Hyltenstam (1977) suggest, however, different lexical contexts are also found to influence the development of morphosyntax. This can be seen as intrastage developments.

\section{The Present Study: German and Swedish as L2s}

\section{L2 German and L2 Swedish Corpora}

The data on L2 German derives from a longitudinal study that collected spontaneous language production data of nine Dutch-speaking learners over a period of 2 years (Baten, 2013). At the time of the recordings, the nine learners were attending the same secondary school, located in an urban region of Flanders. Apart from an introductory course on German in the fourth grade of secondary school (with an interval of $1 \mathrm{hr} /$ week), the pupils had no further formal instruction in German. During the 2 years of data collection, the pupils (then aged 17-18 years) 
received formal instruction with an interval of $3 \mathrm{hr} /$ week. German is their third foreign language. Flemish secondary school pupils start with formal instruction in French and English prior to learning German. None of the pupils had experienced significant exposure to natural German input: German was not spoken at home, and none of the pupils had lived in a German-speaking country for a considerable length of time. The only natural exposure to German occurred during occasional tourist visits to German-speaking countries.

For these learners, the six interviews were conducted approximately once every 3 months. Henceforth, these interviews are described as t1-t6. In each interview, the learners were asked to describe and retell a set of cartoons. The cartoons were selected from the Bildgeschichten Vater und Sohn, "the father and son comic strips" (Ohser, 2000). The advantage of these comic strips is that each picture can be described separately, and they give participants the opportunity to address trivial yet amusing points at the end of the comic strips. These comic strips appear well suited to collecting L2 speech samples. The participants spoke freely and focused on the content of the cartoon. The average length of a conversation was approximately $20 \mathrm{~min}$. After the final data were collected, the participants indicated that they enjoyed talking about the father and son cartoons. Therefore, there is little doubt about the participants' spontaneity and that their main focus was conveying the content of the cartoons.

The data on L2 Swedish comes from the longitudinal project "Swedish inside and outside Sweden” (Håkansson \& Norrby, 2010). The aim of this project was to compare the L2 acquisition of Swedish in Sweden (Malmö) and foreign language acquisition of Swedish in Australia (Melbourne).

For the present analysis, data from 17 learners are used: Eight learners from Melbourne (with English as L1) and nine learners from Malmö (with a variety of L1s and English as a L2). ${ }^{4}$ 
The learners were university students studying Swedish as a second/foreign language at a beginner's level. Written data were collected three times over 1 year (t1-t3). For each datacollection time, the learner wrote one essay and one translation. The translation was used as a method to elicit inverted main clauses and subordinate clauses that demanded subordinate clause word order (i.e., with sentential adverbs). In addition to the written data, oral data were collected once during the final data collection. The oral data consisted of an interview and a communicative task. After the interview, a specific communicative task was used to obtain a high number of examples of subordinate clauses with sentence adverbials (e.g., Glahn et al., 2001). The task is designed as a game with 12 illustrated cards that portray the performance, or nonperformance, of various activities. There are also larger playing boards, each containing six pictures that match those on the separate cards. The players (e.g., the learner and interviewer) take cards in alternative turns, describe which action is performed on the card (e.g., Jag fick kortet med mannen som inte sjunger "I got the card with the man who does not sing"), and place them on top of the matching illustrations on the boards. The person who fills his or her board(s) first wins the game. To introduce the game and the vocabulary used, the learner first described each activity on the cards by using main clauses. This introduction was important to establish that the learners knew the placement of negation in main clauses (after the finite verb), which is different from its placement in subordinate clauses (in front of the finite verb). The participants then drew a card and were asked to describe its content. By this method, it was possible to elicit 12 examples of negated subordinate clauses, six clauses with main verbs and six clauses with auxiliary or modal verbs. The use of a game to elicit linguistic structures has the advantage of diverting the subjects' attention from the formal aspects of language by engaging them in a 
communicative situation; at the same time, the informality of the situation makes it possible for the learners to use main clauses instead of subordinate clauses.

\section{Data Analysis}

In the following sections, we first present the ratio of subordinate clauses for both L2 German and L2 Swedish as they are measured in CAF research (i.e., dependent clause/total clauses). Then, we discuss the acquisition of the internal word order structure for L2 German and L2 Swedish separately. Here, we apply the emergence criterion, which is the acquisition criterion used in PT research. Emergence can be defined as the "point in time corresponding to the first systematic and productive use of a structure" (Pallotti, 2007, p. 366). By systematic and productive use, we mean that memorized chunks must be excluded from analysis. In a way, "first" is somewhat contradictory because a sufficient quantity of contexts is required. After all, "first" does not involve an isolated case but should be embedded in a number of different contexts. In the research field, the minimal number of contexts considered necessary to claim that a structure has emerged varies among researchers, ranging from one (Glahn et al., 2001) to three (Dulay \& Burt, 1974; Zhang, 2005), four (Jansen, 2008; Meisel et al., 1981; Pienemann, 1998; Zhang, 2004), and even five (Andersen, 1978; Pienemann, 1998).

In the current study, we adopt the rationale that learners have to use different verb types (e.g., main verbs and auxiliary or modal verbs) in subordinate clauses for us to be able to state that the subordinate clause word order rule has actually been acquired. In other words, we add verb type variation (i.e., main verbs and auxiliaries or modals) to the emergence criterion. In the PT paradigm, it is common to consider lexical variation in regard to determining the acquisition of morphological rules (e.g., the acquisition of subject-verb agreement), both on a lexical level (e.g., he walks, he sings) and a word type level (e.g., agreement with copulas vs. lexical verbs) 
(Pienemann, 1998, p. 124 and the following pages). In the acquisition of syntactic structures, one productive example is considered sufficient. To distinguish between the productive use of a structure and its use as an unanalyzed chunk the following line of reasoning will be adopted in the present study: A specific structure is recognizable as an unanalyzed chunk when the identical structure occurs several times invariantly and when these structures are the only examples. In practice this means that within the particular verb type (either main verb or auxiliary or modal), there must be more than one example of the structure for it to be regarded as having emerged in the learner's grammar.

The emergence criterion describes the beginning of the acquisition process and allows us to reveal stages. The criterion is in line with the speech processing point of view of PT, as it "can be understood as the point in time at which certain skills have, in principle, been attained or at which certain operations can, in principle, be carried out" (Pienemann, 1998, p. 138). It is assumed that if certain skills are not available, then the linguistic structures reflecting those skills will not emerge in the learner's IL, not even to a minimal extent. Only when the linguistic skills are available, the corresponding linguistic structures will appear; evidently, to a minimal extent first. In addition, the processing perspective of PT also implies that it can be assumed that once a structure has emerged, it will remain a constant part of the IL system at later levels of development (e.g., continuity hypothesis, Pienemann, 1998, p. 147).

For the German data, we examine all subordinate clauses; for the Swedish data, we only analyze subordinate clauses containing an adverbial because the opposition between main clauses and subordinate clauses is determined by the placement of the sentential adverbial. In this study, we do not make a distinction between different complementizers and as such between different types of subordinate clauses. Learners may perhaps use the subordinate clause word 
order rule with certain complementizers but not with others (e.g., Pienemann, 1998, p. 107). Because our study focuses on syntactic development, we will not further examine lexical aspects, neither in relation to the emergence criterion nor in relation to the ratio measure.

Before we move on to the results, it is necessary to address our theoretical or methodological stance towards the different learning contexts studied and the different data elicitations tasks used in our study. We adopt the logic of the so-called hypothesis space, which is an essential aspect of PT (Pienemann, 1998, p. 231 and the following pages), and which refers to the range of structural hypotheses that are available at any one stage of the processability hierarchy. The notion of hypothesis space can be traced back to the multidimensional model in SLA (Meisel, Clahsen, Pienemann, 1981), which likewise differentiated between a vertical and a horizontal dimension in the acquisition process (i.e. between [steady] development and variation, respectively). This differentiation implies that different tasks and different learning contexts will affect the horizontal level (evident through, e.g., fluctuations in correctness levels), but not the vertical level. It is important to note here that the variation at the horizontal dimension does not exist in a theoretical vacuum; instead, the processing constraints (at the vertical level) define $a$ priori the range of variation that is structurally possible.

\section{Results}

\section{L2 German and L2 Swedish Subordination Ratios}

All L2 German learners used subordinate clauses from the start of data collection (except for two learners, CHA and TIN). The subordination ratios differed greatly according to the data point, however (see Figure 1).

INSERT FIGURE 1 ABOUT HERE 
At $\mathrm{t} 1$, the lowest ratio is 0 , and the highest is .14. At the later data points, the range is .13-.31 at $\mathrm{t} 2, .07-.18$ at $\mathrm{t} 3, .09-.26$ at $\mathrm{t} 4, .04-.20$ at $\mathrm{t} 5$, and $.05-.24$ at $\mathrm{t} 6$. These ranges clearly indicate that the nine participants in this study differ greatly in their use of subordinate clauses. Indeed, over the six interviews, the participants did not evolve linearly, as their individual ratios follow a pattern of increases and decreases (see Figure 2).

\section{INSERT FIGURE 2 ABOUT HERE}

Taking into account only the data points at the extreme ( $\mathrm{t} 1$ and $\mathrm{t} 6$ ), however, an overall increase can be observed for all participants.

The same picture emerges from the data of L2 Swedish learners. All L2 Swedish learners used subordinate clauses at the first data point. The subordination ratio varies between .08 and .46 at $\mathrm{t} 1$, between .10 and .46 at $\mathrm{t} 2$, and between .11 and .53 at $\mathrm{t} 3$. Analogous to the $\mathrm{L} 2$ German learners, the individual L2 Swedish learners did not evolve linearly but followed a fluctuating pattern, either showing a decrease toward $\mathrm{t} 2$ and an increase toward $\mathrm{t} 3$ or, vice versa, showing an increase toward $\mathrm{t} 2$ and a decrease toward t 3 . Figure 3 displays the development for the L2 Swedish learners in Melbourne and Figure 4 the development for the learners in Malmö.

INSERT FIGURE 3 ABOUT HERE

INSERT FIGURE 4 ABOUT HERE 
As can be seen in these figures, the individual data does not give a linear growth of subordination as the learners' proficiency increases. The developmental picture of subordination ratios in L2 German and L2 Swedish is reminiscent of what Larsen-Freeman (2006) found in her longitudinal study of five Chinese learners. She too established that the group data suggested an ascending trend, but when the individual data were examined, the lines between the different data points sometimes went up and sometimes went down.

Informed by PT, we believe that we do not have to count the mere existence of subordinate clauses, as it is not subordination in itself that is difficult. Rather, the internal structure should be examined. In fact, when the internal structure remains the same, subordination is not complex at all. In most subordinate clauses in English, for example, there is no difference in the word order of main clauses relative to subordinate clauses, as in the example in (1).

(1) Main clause: he will bring the letter to the princess

Subordinate clause: ..., because he will bring the letter to the princess

when

if

Thus, the learning problem is only of a lexical nature. In L2 English, learners merely need to acquire (the meaning of) complementizers, to which they can add a new clause.

This strategy is unsuitable for L2 German because it yields the wrong word order. Our results show that learners avail themselves of this strategy when first learning German (examples [2] and [3]). For Swedish, subordination involves a specific word order when the clause contains adverbials. This word order is not present in the first uses of subordination, as is illustrated in 
examples (4) and (5). The problems with subordinate clause word order indicate that learners have not yet annotated the (newly) learned lexical item(s) with the necessary grammatical information when they start using subordinate clauses.

(2) MIC: *du siehst dass er brengt den letter nach dem prinzess

"you see that he takes the letter to the princess"

(target: ... dass er der Prinzessin den Brief bringt)

(3) MIC: *er macht eine loch ... in die wand weil sein sohn hat ein spiegel

"he makes a hole ... in the wall because his son has a mirror"

(target: ... weil sein Sohn einen Spiegel hat)

(4) SER: *de turisterna som åker inte på landet åker till en stor stad

"the tourists that go not on the countryside go to a big city"

(target: ... som inte åker på landet ...)

(5) SER: *om man ville inte att andra kunde komma upp ...

"if you wanted not that others could come up ..."

(target: om man inte ville att ...)

These examples show that in the case of L2 German and L2 Swedish, there is a mismatch between the use of subordination and the use of the subordinate clause processing procedures. This suggests that it is necessary to also look at the internal structure of the subordinate clauses used.

\section{Subordinate Clause Word Order in L2 German}

In Table 2, we summarize the development of verb placement in the subordinate clause. Inspired by Hyltenstam's (1977) work on Swedish, we differentiate main verbs and auxiliaries or modal verbs. As a result, we distinguish three stages: (a) the finite verb does (V-End) or does not 
(No V-End) take the final position, either (b) with single main verbs only or (c) with both single main verbs and auxiliaries or modals. ${ }^{5}$ Because of the three-dimensional nature of the data (i.e., participants, data points, stages of verb placement), creating an easily readable table was a challenge. We opted for the graphic method (the actual numbers can be found in the Appendix). In the graphics presented in Figure 5, the squares represent the three previously mentioned stages.

\section{INSERT FIGURE 5 ABOUT HERE}

If a square is colored grey, the corresponding word order rule has been acquired. It should be noted that when both the second and third squares are colored, the first square is evidently overruled. When none of the squares are colored, the learner did not use subordinate clauses.

The German data contain 336 subordinate clauses. Dispersed over data points and number of participants, the mean number of subordinate clauses was six per interview. However, the total number of analyzed subordinate clauses varied across learners, ranging from 22 to 63. We assumed that this range in variation did not affect the results because we adopted the emergence criterion to determine acquisition (Pallotti, 2007). This criterion stipulates that only the first systematic and productive use of a linguistic rule is required to determine whether that particular rule is acquired. In this respect, an overall mean of six subordinate clauses per interview session is considered sufficient. Furthermore, this criterion is compatible with Pallotti’s (2009) “necessary variation fallacy” (p. 590) because it uncovers constants in the variation. The exact number of applications and nonapplications of the V-End rule, both in simple and complex contexts, can be found in the Appendix. 


\section{INSERT TABLE 2 ABOUT HERE}

Table 2 shows that most of the learners produced subordinate clauses from the start of data collection. However, they did not use the subordinate clause word order, except for one learner (ANO), who appeared to be able to put the single main verb in the final position, as in (6). She did not apply the V-End rule, however, when an auxiliary (here, a modal verb) was involved, as in (7). In (6) and (7), [///] indicates a long pause.

(6) ANO: während er euh eine be [I/I] wacht [= dutch] [I/I] ein verbeugung macht "while he uh a be [///] wait [///] a bow makes"

(7) ANO: *eine passant euh sagt dat [=dass] sie mussen halten

"a passer-by uh says that they must stop" (target: ... dass sie aufhören sollten)

From $\mathrm{t} 2$ onward, all learners used subordinate clauses. A closer look at the table shows that only one learner was able to place the finite verb in the final position, both with single main verbs as in (8) and auxiliaries as in (9).

$$
\begin{aligned}
& \text { SIL: ... dass es nicht weh tut } \\
& \text { “... that it not hurt does" }
\end{aligned}
$$

(9) SIL: der lehrer euh sagt dass der hausaufsatz nicht gut gemackt ist

"the teacher uh says that the school.essay not well done is"

At this time point (t2), six learners (ANO, CHA, DOR, MIC, JEL and STI) applied the V-End rule for single main verbs, as in (10) but not when auxiliaries were involved, as in (11).

(10) MIC: er geht naar [:nach] sein zimmer und er sieht dass euh sein vader den buch liest 
"he goes to his room and he sees that uh his dad the book reads"

MIC: *und er glaubt nicht dass euh der junge der hausaufsatz hat gemacht

"and he believes not that uh the boy the school.essay has made"

(target: ... dass der Junge den Hausaufsatz gemacht hat)

The data even show that ANO and MIC were never able to produce auxiliaries in the final position in subordinate clauses. The same applies to MYR and TIN.

The other learners, however, advanced to the next stage at $\mathrm{t} 3$ (CHA, DOR and JEL) or at t4 (STI), when they placed the finite auxiliary verb in the final position, as in (12).

JEL: der vater euh denkt dass euh er eine fisch gefangen hat

"the dad uh thinks that uh he a fish caught has"

The development of these four learners suggests that the V-End rule is easier with single verbs. In other words, it shows that the emergence of the V-End rule is conditional upon the distinction between single main verbs and auxiliaries.

On the basis of these findings, we can observe (a) a clear difference between the acquisition and nonacquisition of the V-End rule and (b) a dependence on single main verbs as opposed to auxiliaries or modals. It appears that the acquisition of the V-End rule is postponed in the case of complex VPs. In other words, at the same time when learners can apply the V-End rule with single main verbs, they cannot apply the V-End rule with auxiliaries or modals. When more than one verb is involved, the learners tend to place the infinite verb in the final position. This postponement especially applies when modal verbs are involved, such as in (13).

(13) DOR: *er zeigt das an sein sohn dass euh er nicht euh keine angst musst haben

"he shows it to his son that uh he not he // no fear need.to have" (target: ... dass er keine Angst haben sollte) 
Differentiating between auxiliaries and modals, the data seems to suggest that the application of the V-End rule with modals is more difficult. In the data for CHA, for example, the emergence of the V-End rule with auxiliaries preceded the emergence of the rule with modals. In addition, JEL and DOR did not ever apply the V-End with modals. Their use of the V-End rule remained restricted to auxiliaries. If we present the distinction between auxiliaries (AUX) and modals (MOD) in a distribution, according to either the target (V-End) or nontarget (No V-End) rule application, we obtain the results in Table 3. The numbers represent the totals of all data points and all participants.

\section{INSERT TABLE 3 ABOUT HERE}

The table shows a significant difference regarding the rule application between auxiliaries and modals. As a result, we conclude that L2 German subordinate clause use develops as follows: No V-End $<$ V-End with single main verbs $<$ V-End with more than one verb (auxiliaries) $<$ VEnd with more than one verb (modals).

\section{Subordinate Clause Word Order in L2 Swedish}

A close look at the internal structure of the L2 Swedish subordinate clauses reveals that although all learners used subordination from the start, their use of subordinate clause word order developed gradually. In total, the Swedish data comprise 398 subordinate clauses. Of these, 176 clauses are neutral with respect to word order, whereas 222 clauses contain sentential adverbials (e.g., negations), which is the requirement for the subordinate clause word order. These 222 clauses were subjected to closer analysis. The mean value for this type of subordinate clause was four per interview, ranging from 4 to 20 per individual learner. 
Similar to the presentation for L2 German, we summarize the development of the verb placement in the L2 Swedish subordinate clauses by distinguishing three stages: (a) the finite verb takes the second position, and the adverbial comes after the verb; (b) the single main verb takes the third position following the adverbial; and (c) both the single main verb and the auxiliary or modal verb take the third position following the adverbial.

\section{INSERT FIGURE 6 ABOUT HERE}

Tables 4 and 5 show the results from L2 Swedish in the Melbourne and Malmö groups, respectively.

\section{INSERT TABLE 4 ABOUT HERE}

When the different VPs are taken into consideration, we find that although all the Melbourne learners used subordination from the start, only six of them eventually used the subordinate clause word order, and only two (SER and CEI) used the subordinate clause word order with modal verbs.

\section{INSERT TABLE 5 ABOUT HERE}

The results from the Malmö group demonstrate that these learners, living in Sweden, are more advanced than those in the Melbourne group. However, the tendencies are the same. They all used subordinate clauses from the beginning, but only one of the learners managed to use the 
internal word order $\mathrm{Adv}+\mathrm{V}$. At $\mathrm{t} 2$, three more learners used $\mathrm{Adv}+\mathrm{V}$ with main verbs, but no one used $\mathrm{Adv}+\mathrm{V}$ with modal verbs. At $\mathrm{t} 3$, seven learners used $\mathrm{Adv}+\mathrm{V}$ with main verbs, and five out of nine used $\mathrm{Adv}+\mathrm{V}$ with modal verbs.

To illustrate the variation between main and modal verbs, consider the following examples, taken from the Malmö group. At t1, LER used Adv + V with main verbs, as in (14), but not with modal verbs, as in (15).

(14) LER: de som inte reser till landet reser till en stad (t1)

"those who not go to the country, go to a city"

(15) LER: *det var ett helt år som jag kunde inte gå (t1)

"it was a whole year that I could not walk"

(target: ... som jag inte kunde gå)

These sentences indicate that the acquisition of the subordinate clause order is conditional upon the complexity of the VP. This difference in VP complexity is also present in the data of SAN, who shows a complete picture of language development: At t1, she did not use Adv+V at all; at $\mathrm{t} 2$, she used it with main verbs, as in (16), but not with modal verbs; finally, at $\mathrm{t} 3$, she also used it with modal verbs, as in (17).

(16) SAN: det är många barn som inte har ens en leksak (t2)

"there are many children who not have even one toy"

(17) SAN: jag fick den som inte kan flyga (t3)

"I got the one that not can fly"

Clearly, the use of modal verbs increases the complexity of the subordinate clause; as a result, learners seem to adopt evasion strategies. In (18), for example, JAL talks about the card she took (in the oral communicative task at $\mathrm{t} 3$ ). She hesitates and reformulates her original sentence with a 
modal verb and postposed negation into a construction with a single main verb and preposed negation. In so doing, she changes the context and makes the utterance easier to process.

JAL: jag har en pojke som vill inte måla euh eller som inte målar (t3)

"I have a boy who will not paint euh or who not paint"

In summary, we conclude that L2 Swedish subordinate clause use develops as follows:

$\mathrm{No}$ Adv/Neg $+\mathrm{V}<\mathrm{Adv} / \mathrm{Neg}+\mathrm{V}$ with single main verbs $<\mathrm{Adv} / \mathrm{Neg}+\mathrm{V}$ with more than one verb (modals)

\section{Discussion}

This paper began with the idea that CAF measures (including subordination ratios) may not always be valid indicators of L2 development. Dynamic systems theory studies have used these measures to demonstrate that L2 development is unpredictable and not universally stagelike. Instead of using a CAF approach, we adopted an implicationally emerging processing skill approach, which has shown that the internal structure develops in a clear sequence.

In line with previous DST research results (e.g., Larsen-Freeman, 2006; Verspoor et al., 2012), our subordination ratios revealed a fluctuating pattern. The fluctuation shows that the use of subordinate clauses differs according to participant and data point. Among other things, ${ }^{6}$ the fluctuating pattern most likely results from an effect of the tasks used during data collection (e.g., Robinson, 2011; Skehan \& Foster, 2009). Not every cartoon or essay assignment was well suited to the use of subordinate clauses. Obviously, some of the cartoons or essay assignments triggered the production of subordinate clauses more than others. However, every cartoon and essay assignment did yield subordinate clauses by some learners.

In other words, the subordination ratio used in the present study and the CAF measures in general appear to be valid measures to reveal variation (which is caused by a variety of factors, 
such as different tasks and different learning contexts). However, the CAF measures cannot be used as indicators of L2 development, because they are not operationalized as such. In DST, it seems that the definition and operationalization of variation and development coincide. On the contrary, PT adheres to the view that development and variation are two separate dimensions of SLA (e.g., Meisel et al., 1981). In PT, L2 development is operationalized by means of the emergence criterion, which is better suited to capture L2 stages.

One of the reviewers wondered if such factors as different tasks do not also influence the emergence criterion (as it clearly influences the complexity measure). We would argue that this is not the case, because the emergence of a specific syntactic rule represents the one cutoff point that remains constant. It represents the vertical dimension of the acquisition process, which is characterized by an implicational relationship of the processing procedures. The variation due to task differences, on the other hand, reflects the horizontal dimension, which refers to the range of possible structural hypotheses at any one stage, but which is at the same time constrained by the processing procedure of that stage. This two-dimensional approach to SLA is conceptualized as hypothesis space in PT.

In this context, Pienemann (1998) additionally proposes the steadiness hypothesis, which predicts that "the basic nature of the grammatical system of an IL does not change in different communicative tasks as long as those are based on the same skill type in language production" (p. 273). This means that learners' stages are stable across different tasks. Also, when a stage has emerged, it will be a constant part of the IL system at later levels of development (e.g., continuity hypothesis, Pienemann, 1998, p. 147). This means that a linguistic structure can be regarded as having emerged in a particular data sample, but may not have emerged in a subsequent sample. Pallotti (2007, p. 368) gave two explanations for this apparent non- 
emergence: first, the IL of the learner involved may experience some backsliding; second, the subsequent data sample may not provide sufficient contexts to determine the status of emergence of the linguistic structure at issue. In spite of this, it can be assumed that the linguistic rule is still part of the IL grammar but that it does not appear in the IL productions.

The logic of the hypothesis space can also be applied to the different learning contexts that were studied in the present study. Our study involved foreign language learners of German, foreign language learners of Swedish, and L2 learners of Swedish. These different contexts will obviously have influenced the acquisition process but, in our opinion, only in terms of the rate of acquisition, not in terms of the route of acquisition. Indeed, the Malmö group turns out to be more advanced than the Melbourne group. Nevertheless, irrespective of the learning context, every single learner reshapes his or her IL grammar according to the chronology of new processing procedures that emerge. Recall that the L2 studies on German word order also revealed the same sequence, irrespective of the learning context.

Adopting the emergence criterion, our results demonstrate that although the use of subordinate clauses was present during all data points, albeit to varying degrees, the development of the internal structure followed a clear and constant implicational sequence. In summary, the use of subordinate clauses in L2 Swedish develops as SUB > Adv + V (simple VP) > Adv + V (complex VP), whereas the use of subordinate clauses in L2 German develops as SUB (No VEnd) $>$ V-End (simple VP) > V-End (complex VP). L2 Swedish and L2 German learners used subordinate clauses from the beginning (with two exceptions in the L2 German group, who only started using subordinate clauses from $\mathrm{t} 2$ onward [CHA; TIN]). The immediate use of subordinate clauses did not mean, however, that the learners had reached the subordinate clause level in the PT hierarchy, because they did not necessarily simultaneously use the distinctive 
subordinate clause word order from the start. The internal structure emerged only later and in distinct phases. The subordinate clause word order occurred first with single main verbs only and afterward with complex VPs, including auxiliaries and modals. In the L2 German data, we found that the acquisition of the subordinate clause word order in subordinate clauses with complex VPs even depended on the verb type, where VPs with modals were more complex than VPs with auxiliaries. The same trend was observed in the L2 Swedish data, but more data (with more verb type variation) are needed to warrant such a conclusion.

With these results, our study replicates findings of L1 research. Müller (1993), for example, observed differences between the placement of main verbs and the placement of auxiliaries or modals in the German subordinate clauses of a French-German bilingual child. The child first applies the V-End rule with main verbs and only later with auxiliaries and modals. Similarly, for L1 Swedish, Håkansson and Dooley Collberg (1994) found an implicational order between modal and main verb contexts so that the subordinate clause word order was first used in the context of a main verb before it was used in modal contexts.

The present study compared linguistic complexity as measured by subordination ratios with the emergence of internal word order structures. Seeing that the emergence of the subordinate clause procedure relies on the use of the specific word order rule in L2 German and L2 Swedish, one reviewer wondered if the emergence criterion is not stepping into the territory of the accuracy dimension of the CAF triad. This is most certainly not the case. Whereas accuracy in the CAF research tradition refers to the relation of accurate and inaccurate uses of a certain structure (e.g., $80 \%$ accurate vs. $20 \%$ inaccurate), the emergence criterion in the PT research tradition looks at the first productive use of a certain structure. As was illustrated in Table 1, some PT stages involve structures that are part of the target language (e.g., INV at stage 
4 and V-End/V3 at stage 5), whereas other PT stages contain structures that are not part of the target language (e.g., ADV at stage 3 is not part of either German or Swedish but still used in learner language). This being said, had we compared the accuracy and the emergence of the subordinate word order, our argument and our findings would have been the same: Just like complexity ratios, accuracy rates do not actually picture development but rather indicate the variation between and within individual learners. An analysis of accuracy rates would indeed show interindividual and intraindividual variation, but this variation and variability would not constitute evidence against stagelike development.

In sum, the findings on L2 German and L2 Swedish in this article are meant as a refutation of the DST claims that developmental stages do not exist and that L2 development is actually unpredictable. What we find particularly problematic is the way the DST approach seems to operationalize L2 development. As we understand it, L2 development is operationalized in terms of the CAF measures and as such, in terms of frequency measures, such as mean scores, rates, and ratios. However, no rationale is provided for this equation. ${ }^{7}$ Our argument is not to abandon CAF measures altogether but not to use them as indicators of L2 development as DST does. As long as the DST framework does not clearly define and operationalize L2 development, they cannot simply interpret CAF measures as evidence that learners do not progress in fixed stages. In addition, the DST framework should make explicit the level of predictability they are talking about. Although it is indeed impossible to predict the exact pattern in terms of rates and ratios, it is possible, as we have shown, to predict an implicational sequence in terms of emergence.

\section{Conclusion}


With the claim "that the general developmental stages individuals go through are much less similar than we have assumed so far" (de Bot, Lowie, \& Verspoor, 2005, p. 24), DST challenges a long-standing finding in SLA research that L2 development occurs in stages. In PT, this steady development in stages (as well as the variation, for that matter) is explained by processing constraints. The aim of the present paper was to show that developmental stages do exist and can be lexically governed. Using PT as a framework and its emergence criterion as an operationalization of L2 development, we were able to find clear (intra)stages in the development of subordinate clause word order in L2 German and Swedish. What is more, we were able to formulate testable hypotheses in advance, which is something that the DST framework does not enable us to do. As they acknowledge themselves (de Bot et al., 2007) "the DST approach is much more geared towards visualization to see developments rather than to test them" (p. 14). We have shown, however, that CAF measures are not the right measures to visualize developmental stages. Instead, using the emergence criterion we were able to bring to light that the lexicon (in the sense of verb types) is a driving force in morphosyntactic development.

Received 16 August 2013

Accepted 11 April 2014

Final Version Received 20 May 2014 


\section{References}

Abrahamsson, N. (2013). Developmental sequences. In P. Robinson (Ed.), The Routledge Encyclopedia of Second Language Acquisition (pp. 173-177). London, UK: Routledge.

Andersen, R. W. (1978). An implicational model for second language research. Language Learning, 28(1), 221-282.

Baten, K. (2013). The acquisition of the German case system by foreign language learners. Amsterdam, the Netherlands: Benjamins.

Beaman, K. (1984). Coordination and subordination revisited: Syntactic complexity in spoken and written narrative discourse. In D. Tannen (Ed.), Coherence in spoken and written discourse (pp. 45-80). Norwood, NJ: Ablex.

Boss, B. (1996). German grammars for beginners: The teachability hypothesis and its relevance to the classroom. The University of Queenland Papers in Language and Linguistics, 1, 93-100.

Bulté, B., \& Housen, A. (2012). Defining and operationalising L2 complexity. In A. Housen, F. Kuiken, \& I. Vedder (Eds.), Dimensions of L2 performance and proficiency (pp. 21-46). Amsterdam, the Netherlands: Benjamins.

Caspi, T. (2010). A dynamic perspective on second language development (Unpublished doctoral dissertation, University of Groningen, the Netherlands). Retrieved from http://irs.ub.rug.nl/ppn/329338412

Clahsen, H. (1984). The acquisition of German word order: A test case for cognitive approaches to L2 development. In R.W. Andersen (Ed.), Second languages: A cross-linguistic perspective (pp. 219-242). Rowley, MA: Newbury House. 
Clahsen, H., Meisel, J., \& Pienemann, M. (1983). Deutsch als Zweitsprache: der Spracherwerb ausländischer Arbeiter [German as a second language: The language acquisition of foreign workers]. Tübingen, Germany: Narr Verlag.

de Bot, K., Lowie, W., Thorne, S. L., \& Verspoor, M. (2013). Dynamic systems theory as a theory of second language development. In M. Mayo, M. Gutierrez-Mangado, \& M. Adrián (Eds.), Contemporary approaches to second language acquisition (pp. 199-220). Amsterdam, the Netherlands: Benjamins.

de Bot, K., Lowie, W. \& Verspoor, M. (2005). Second language acquisition: An advanced resource book. London, UK: Routledge.

de Bot, K., Lowie, W., \& Verspoor, M. (2007). A dynamic systems theory approach to second language acquisition. Bilingualism: Language and Cognition, 10, 7-21.

Dryer, M. S. (2008). Order of subject, object, and verb. In M. Haspelmath, M. S. Dryer, D. Gil, \& B. Comrie (Eds.), The world atlas of language structures online (Chapter 81). Retrieved from http://wals.info/chapter/81

Dulay, H. C., \& Burt, M. K. (1974). Natural sequences in child second language acquisition. Language Learning, 24(1), 37-53.

Ellis, R. (1989). Are classroom and naturalistic acquisition the same? A study of the classroom acquisition of German word order rules. Studies in Second Language Acquisition, 11, 303-328.

Gayraud, F., \& Martinie, B. (2008). Does structural complexity necessarily imply processing difficulty? Journal of Psycholinguist Research, 37, 21-31. 
Glahn, E., Håkansson, G., Hammarberg, B., Holmen, A., Hvenekilde, A., \& Lund, K. (2001). Processability in Scandinavian second language acquisition. Studies in Second Language Acquisition, 23, 389-416.

Haberzettl, S. (2005). Der Erwerb der Verbstellungsregeln in der Zweitsprache Deutsch durch Kinder mit russischer und türkischer Muttersprache [The acquisition of verb-position rules in German as a second language by school-age native speakers of Turkish and Russian]. Tübingen, Germany: Niemeyer.

Håkansson, G. (2001). Tense morphology and verb-second in Swedish L1 children, L2 children and children with SLI. Bilingualism: Language and Cognition, 4, 85-99.

Håkansson, G., \& Dooley Collberg, S. (1994). The preference for modal + neg: An L2 perspective applied to L1 acquisition. Second Language Research, 10, 95-124.

Håkansson, G., \& Nettelbladt, U. (1993). Developmental sequences in L1 and L2 acquisition of Swedish syntax. International Journal of Applied Linguistics, 3, 3-29.

Håkansson G., \& Norrby, C. (2007). Processability theory applied to written and oral L2 Swedish. In F. Mansouri (Ed.), Second language acquisition research: Theoryconstruction and testing (pp. 81-94). Cambridge, UK: Cambridge Scholars Press.

Håkansson, G., \& Norrby, C. (2010). Environmental influence on language acquisition: Comparing second and foreign language acquisition of Swedish. Language Learning, 60, $628-650$.

Hammarberg, B., \& Viberg, A. (1977). The place-holder constraint, language typology and the teaching of Swedish to immigrants. Studia Linguistica, 31, 106-163.

Housen, A., \& Kuiken, F. (2009). Complexity, accuracy, and fluency in second language acquisition. Applied Linguistics, 30, 461-473. 
Hyltenstam, K. (1977). Implicational patterns in interlanguage syntax variation. Language Learning, 27, 383-411.

Jakobson, R. (1941). Kindersprache, Aphasie und allgemeine Lautgesetze [Child language, aphasia, and phonological universals]. Uppsala, Sweden: Almqvist \& Wiksell.

Jansen, L. (2008). Acquisition of German word order in tutored learners: A cross-sectional study in a wider theoretical context. Language Learning, 58, 185-231.

Larsen-Freeman, D. (1997). Chaos/complexity science and second language acquisition. Applied Linguistics, 18, 148-165.

Larsen-Freeman, D. (2006). The emergence of complexity, fluency, and accuracy in the oral and written production of five Chinese learners of English. Applied Linguistics, 27, 590-619.

Larsen-Freeman, D. \& Cameron, L. (2008). Complexity systems and applied linguistics. Oxford, UK: Oxford University Press.

Levelt, W. (1989). Speaking: From intention to articulation. Cambridge, MA: MIT Press.

Long, M. H. (2007). Problems in SLA. Mahwah, NJ: Erlbaum.

Meerholz-Härle, B. \& Tschirner, E. (2001). Processability theory: eine empirische Untersuchung [An empirical study]. In K. Aguado \& C. Riemer (Eds.), Wege und Ziele: Zur Theorie, Empirie und Praxis des Deutschen als Fremdsprache (und anderer Fremdsprachen). Festschrift für Gert Henrici [Paths and goals: On theory, empirical evidence and professional practice of German as a second language (and other languages). Festschrift for Gert Henrici.] (pp. 155-175). Hohengehren, Germany: Schneider.

Meisel, J. M. (2013). Development in second language acquisition. In P. Robinson (Ed.), The Routledge encyclopedia of second language acquisition (pp. 165-173). London, UK: Routledge. 
Meisel, J., Clahsen, H., \& Pienemann, M. (1981). On determining developmental stages in natural second language acquisition. Studies in Second Language Acquisition, 3, 109-135.

Müller, N. (1993). Komplexe Sätze. Der Erwerb von COMP und von Wortstellungsmustern bei bilingualen Kindern (Französisch/Deutsch) [Complex sentences. The acquisition of COMP and word order rules by bilingual children (French/German)]. Tübingen, Germany: Narr.

Norris, J., \& Ortega, L. (2009). Towards an organic approach to investigating CAF in instructed SLA: The case of complexity. Applied Linguistics, 30, 555-578.

Ohser, E. (2000). Politische Karikaturen, Zeichnungen, Illustrationen und alle Bildgeschichten Vater und Sohn [Political cartoons, drawings, illustrations and all picture stories of father and son]. Konstanz, Germany: Südverlag.

Pallotti, G. (2007). An operational definition of the emergence criterion. Applied Linguistics, 28, 361-382.

Pallotti, G. (2009). CAF: Defining, refining, and differentiating constructs. Applied Linguistics, $30,590-601$.

Pallotti, G. (2013, August). A simple view of linguistic complexity. Paper presented at the EuroSLA conference, Amsterdam, the Netherlands.

Philipsson, A. (2007). Interrogative clauses and verb morphology in L2 Swedish: Theoretical interpretations of grammatical development and effects of different elicitation techniques (Unpublished doctoral dissertation). Stockholm University, Sweden.

Pienemann, M. (1980). The second language acquisition of immigrant children. In S. Felix (Ed.), Second language development: Trends and issues (pp. 41-56). Tübingen, Germany: Narr. 
Pienemann, M. (1984). Psychological constraints on the teachability of languages. Studies in Second Language Acquisition, 6, 186-214.

Pienemann, M. (1989). Is language teachable? Psycholinguistic experiments and hypotheses. Applied Linguistics, 10, 52-79.

Pienemann, M. (1998). Language processing and second language development: Processability theory. Amsterdam, the Netherlands: Benjamins.

Pienemann, M. (2005). Cross-linguistic aspects of processability theory. Amsterdam, the Netherlands: Benjamins.

Pienemann, M., \& Håkansson, G. (1999). A unified approach toward the development of Swedish as L2: A processability account. Studies in Second Language Acquisition, 21, $383-420$.

Rahkonen, M., \& Håkansson, G. (2008). Production of written L2-Swedish - processability or input frequencies? In J.-U. Kessler (Ed.), Processability approaches to second language development and second language learning (pp. 135-161). Cambridge, UK: Cambridge Scholars Press.

Robinson, P. (2011). Second language task complexity: Researching the cognition hypothesis of language learning and performance. Amsterdam, the Netherlands: Benjamins.

Schönström, K. (2010). Tvåspråkighet hos döva skolelever. Processbarhet och narrativ struktur $i$ svenska och svenskt teckenspråk [Bilingualism in deaf pupils. Processability and narrative structure in Swedish and Swedish sign language] (Unpublished doctoral dissertation). Stockholm University, Sweden. 
Skehan P., \& Foster, P. (2009). The influence of planning and task type on second language performance. In K. Van den Branden, M. Bygate, \& J. Norris (Eds.), Task-based language teaching: A reader (pp. 275-300). Amsterdam, the Netherlands: Benjamins.

Spoelman, M., \& Verspoor, M. (2010). Dynamic patterns in development in accuracy and complexity: A longitudinal case study in the acquisition of Finnish. Applied Linguistics, $31,532-553$.

VanPatten, B., \& Williams, J. (2007). Theories in second language acquisition. Mahwah, NJ: Erlbaum.

Verspoor, M., de Bot, K., \& Lowie, W. (2011). A dynamic systems approach to second language development: Methods and techniques. Amsterdam, the Netherlands: Benjamins.

Verspoor, M., Lowie, W., \& Dijk, M. (2008). Variability in second language development from a dynamic systems perspective. Modern Language Journal, 92, 214-231.

Verspoor, M., Schmid, M. S., \& Xu, X. (2012). A dynamic usage based perspective on L2 writing development. Journal of Second Language Writing, 21, 239-263.

Wolfe-Quintero, K., Inagaki, S., \& Kim, H.-Y. (1998). Second language development in writing: Measures of fluency, accuracy and complexity. Honolulu, HI: University of Hawai 'i Press.

Zhang, Y. (2004). Processing constraints, categorial analysis, and the second language acquisition of the chinese adjective suffix -de(ADJ). Language Learning, 54(3), 437-468.

Zhang, Y. (2005). Processing and formal instruction in the L2 acquisition of five chinese grammatical morphemes. In M. Pienemann (Ed.), Cross-linguistic aspects of processability theory (pp. 155-177). Amsterdam, the Netherlands: Benjamins. 


\section{Appendix}

Table A1 The Development of the V-End rule in L2 German Subordinate Clauses (Simple and Complex)

\begin{tabular}{|c|c|c|c|c|c|c|c|c|c|}
\hline Data point & TIN & MYR & $\mathrm{MIC}$ & ANO & STI & CHA & DOR & JEL & SIL \\
\hline \multicolumn{10}{|l|}{ Simple } \\
\hline $\mathrm{t} 1$ & $0 / 0$ & $0 / 3$ & $0 / 1$ & $2 / 2$ & $0 / 0$ & $0 / 0$ & $0 / 0$ & $0 / 4$ & $0 / 0$ \\
\hline $\mathrm{t} 2$ & $1 / 2$ & $1 / 2$ & $4 / 4$ & $2 / 2$ & $2 / 2$ & $2 / 2$ & $8 / 8$ & $2 / 2$ & $2 / 2$ \\
\hline $\mathrm{t} 3$ & $0 / 0$ & $3 / 3$ & $1 / 1$ & $3 / 3$ & $2 / 2$ & $1 / 1$ & $6 / 6$ & $2 / 2$ & $0 / 1$ \\
\hline $\mathrm{t} 4$ & $6 / 7$ & $1 / 1$ & $4 / 4$ & $3 / 4$ & $7 / 7$ & $1 / 1$ & $5 / 5$ & $8 / 8$ & $1 / 1$ \\
\hline $\mathrm{t} 5$ & $1 / 1$ & $3 / 4$ & $6 / 8$ & $3 / 3$ & $1 / 1$ & $1 / 1$ & $8 / 8$ & $3 / 3$ & $1 / 1$ \\
\hline t6 & $3 / 3$ & $2 / 2$ & $10 / 12$ & $3 / 3$ & $4 / 4$ & $3 / 3$ & $7 / 7$ & $3 / 4$ & $2 / 2$ \\
\hline
\end{tabular}

Complex

$\begin{array}{lllllllllll}\mathrm{t} 1 & 0 / 0 & 0 / 0 & 0 / 0 & 0 / 1 & 0 / 1 & 0 / 0 & 0 / 1 & 0 / 0 & 0 / 1 \\ \mathrm{t} 2 & 0 / 6 & 1 / 3 & 0 / 5 & 0 / 2 & 1 / 5 & 1 / 4 & 1 / 4 & 0 / 7 & 4 / 6 \\ \mathrm{t} 3 & 0 / 0 & 0 / 0 & 0 / 3 & 0 / 1 & 1 / 5 & 2 / 2 & 3 / 3 & 2 / 2 & 2 / 3 \\ \mathrm{t} 4 & 0 / 0 & 1 / 3 & 0 / 3 & 1 / 1 & 5 / 5 & 2 / 2 & 6 / 8 & 2 / 3 & 2 / 2\end{array}$




\begin{tabular}{|c|c|c|c|c|c|c|c|c|c|}
\hline t5 & $0 / 0$ & $1 / 3$ & $0 / 2$ & $0 / 0$ & $1 / 2$ & $1 / 1$ & $4 / 5$ & $3 / 6$ & $3 / 3$ \\
\hline t6 & $1 / 3$ & $0 / 1$ & $0 / 4$ & $0 / 2$ & $1 / 1$ & $3 / 4$ & $1 / 3$ & $0 / 5$ & $1 / 1$ \\
\hline
\end{tabular}

Note. The number after the slash indicates the obligatory context; before the slash is the actual application of the V-End rule. Hence, the difference of both yields the number of nonapplications. With the slightly lighter shade of grey we want to indicate that the subordinate clause word order rule is still to be considered as emerged, following the continuity hypothesis (Pienemann, 1998, p. 147). The darker shade indicates that the rule has emerged, following the emergence criterion.

Table A2 The Development of the ADV + verb Rule in L2 Swedish Subordinate Clauses (Simple and Complex), Melbourne Group

\begin{tabular}{lcccccccc}
\hline Data point & BLE & KER & LEZ & JAS & CAL & JES & SER & CEI \\
\hline Simple & & & & & & & & \\
$\mathrm{t} 1$ & $0 / 2$ & $0 / 0$ & $0 / 0$ & $0 / 0$ & $2 / 2$ & $0 / 1$ & $0 / 0$ & $2 / 3$ \\
$\mathrm{t} 2$ & $0 / 0$ & $0 / 2$ & $1 / 2$ & $2 / 3$ & $1 / 1$ & $0 / 1$ & $0 / 2$ & $2 / 2$ \\
$\mathrm{t} 3$ & $0 / 2$ & $0 / 2$ & $6 / 6$ & $1 / 1$ & $3 / 3$ & $2 / 2$ & $2 / 2$ & $5 / 5$
\end{tabular}

Complex

t1 
Note. The number after the slash indicates the obligatory context; before the slash is the actual application of the ADV + verb rule.

Hence, the difference of both yields the number of nonapplications. With the slightly lighter shade of grey we want to indicate that the subordinate clause word order rule is still to be considered as emerged, following the continuity hypothesis (Pienemann, 1998, p. 147). The darker shade indicates that the rule has emerged, following the emergence criterion.

Table A3 The Development of the ADV + verb rule in L2 Swedish Subordinate Clauses (Simple and Complex), Malmö group

\begin{tabular}{lccccccccc}
\hline Data point & NAL & LER & JAL & SVA & ALI & DHE & SAN & JIL & KAI \\
\hline Simple & & & & & & & & & \\
$\mathrm{t} 1$ & $0 / 0$ & $1 / 1$ & $0 / 0$ & $1 / 1$ & $0 / 2$ & $1 / 1$ & $0 / 2$ & $1 / 1$ & $2 / 2$ \\
$\mathrm{t} 2$ & $1 / 3$ & $1 / 2$ & $0 / 1$ & $2 / 3$ & $1 / 1$ & $1 / 2$ & $2 / 3$ & $2 / 2$ & $1 / 1$ \\
$\mathrm{t} 3$ & $0 / 2$ & $1 / 1$ & $2 / 2$ & $2 / 3$ & $2 / 2$ & $3 / 3$ & $5 / 5$ & $6 / 6$ & $1 / 1$
\end{tabular}

Complex 
Note. The number after the slash indicates the obligatory context; before the slash is the actual application of the ADV + verb rule.

Hence, the difference of both yields the number of nonapplications. With the slightly lighter shade of grey we want to indicate that the subordinate clause word order rule is still to be considered as emerged, following the continuity hypothesis (Pienemann, 1998, p. 147).

The darker shade indicates that the rule has emerged, following the emergence criterion. 


\section{Author Note}

Kristof Baten, Linguistics Department, Ghent University and Research Foundation Flanders (FWO-Vlaanderen); Gisela Håkansson, Centre for Languages and Literature, Lund University.

The authors would like to thank the editorial team and the anonymous reviewers for their valuable comments. Kristof Baten also wishes to thank the Research Foundation Flanders for a travel grant for a research stay at Lund University.

Correspondence concerning this article should be address to Kristof Baten, Linguistics Department, Ghent University, Blandijnberg 2, 9000 Ghent, Belgium, Kristof.Baten@UGent.be. 
Notes

1. It is important to note that subordinate clause word order is the final stage in morphosyntactic development only when a difference between main clause and subordinate clause word order is present.

2. According to the World Atlas of Language Structures, German has no dominant word order in general, yet SVO word order is dominant in main clauses, and subject-object-verb (SOV) word order is dominant in subclauses (Dryer, 2008).

3. One exception is the indirect question, in which the word order of the subordinate clause differs from the word order in the direct question, for example, Has he bought a dog? versus I wonder if he has bought a dog. In PT, this is referred to as cancel inversion, as there is no inversion between the auxiliary and the subject and this structure is placed at the subordinate clause stage (Pienemann, 1998, p. 176).

4. L1: Albanian $(n=1)$, Arabic $(n=2)$, Hungarian $(n=1)$, Japanese $(n=1)$, Rumanian $(n$ $=1)$, Russian $(n=3)$, and Somalian $(n=1)$.

5. Note that the No V-End category comprises $\mathrm{SVO}$, VSO, or $\mathrm{SOV}_{\text {fin }} \mathrm{V}_{\text {inf }}$ word orders; $\mathrm{SOV}_{\text {fin }} \mathrm{V}_{\text {inf }}$ structures are considered $N o V$-End because it is not the finite verb that takes the last position. The Dutch-speaking learners in the present study often use this last word order structure in their L2 German subordinate clauses, which may be due to transfer, because in Dutch both $\mathrm{V}_{\text {inf }}$-End and $\mathrm{V}_{\text {fin }}$-End exist. One could wonder, however, why the one word order option would be transferred and not the other. Seeing that the present paper is not about transfer, we will not further discuss this issue.

6. As mentioned earlier, previous research has shown that the language mode, the degree of syntactic integration, and task complexity affect the use of subordinate clauses. 
7. We would like to mention here that one of the reviewers legitimately asked us to provide a more detailed operationalization of the emergence criterion. It is our impression that this comment hardly ever comes up when studies on L2 development use frequency measures, such as rates and ratios. 